九州大学学術情報リポジトリ

Kyushu University Institutional Repository

\title{
Effect of Different Kinds of Environmental Freindly Materials on the Growth of Rice
}

Lee, Jung Jong

College of Agriculture and Life Sciences, Kyungpook National University

Shon, Tae Kwon

College of Agriculture and Life Sciences, Kyungpook National University

Furuya, Tadahiko

Graduate School of Bioresource and Bioenvironmental Sciences, Kyushu University

Jin, Il-Doo

College of Agriculture and Life Sciences, Sunchon National University

他

https://doi.org/10.5109/9278

出版情報：九州大学大学院農学研究院紀要. 52 (1)，pp.39-42，2007-02-28. Faculty of Agriculture， Kyushu University

バージョン：

権利関係 : 


\title{
Effect of Different Kinds of Environmental Friendly Materials on the Growth of Rice
}

\author{
Jung Jong LEE ${ }^{1}$, Tae Kwon SHON ${ }^{1}$, Tadahiko FURUYA, Il-Doo JIN ${ }^{2}$, \\ Il Kyung CHUNG ${ }^{3}$ and Sang Chul LEE ${ }^{1 *}$
}

\author{
Laboratory of Crop Science, Graduate. School of Bioresource and Bioenvironmental Science, \\ Kyushu University, Fukuoka 812-8581, Japan \\ (Received November 10, 2006 and accepted December 1, 2006)
}

\begin{abstract}
A study was carried out to investigate the effect of environmentally friendly materials on different treatments on paddy soil and loess soil "Hwangto" on the growth characteristics and yield in rice. Some physico-chemical soil properties investigated showed significant values when paddy soil was treated with mixture of charcoal with pyroligneous acid (MCPA), charcoal and pyroligneous acid than in values treated with just paddy soil. Organic matter showed a high figure especially in paddy soil mixed with MCPA. Available phosphorous showed high values in charcoal and MCPA group indicating that there was some soil improvement in that respect. EC was the lowest in Loess soil "Hawngto". Mg content was higher as compared to the rest of the paddy soil treatments. Top dry weight 30 days after transplanting was high with paddy soil mixed with charcoal and MCPA. Root activity was either similar or higher in the various treatments. Plant height was restrained in the early growth but was recovered by the maximum tillering stage in loess soil "Hwangto" treatment. Similarly, chlorophyll content at the maximum tillering stage was highest in loess soil "Hwangto" treatment. Yield components responded differently to the treatments showing highest numbers of tillers, spikelets and panicles with paddy soil mixed with charcoal, PA and MCPA, respectively. These results indicate that these environmentally friendly materials could contribute to improve plant growth and yield in rice.
\end{abstract}

\section{INTRODUCTION}

Over last three decades, farming system has been directed to maximize agricultural production and to increase farmer's income through adoption of high-yielding crop varieties with high input of agro-chemicals (Yoo, 1999). These farming practices have resulted in many problems like food safety, soil fertility, and deterioration of fresh and underground water-quality (Bouwnan, 1990; Duxbury and Moiser, 1993; Jones and Schwab, 1993). Loess soil being one of the important economic consequences of quaternary environmental change, in that it resulted in large areas of soil that have an agriculturally more favorable particle size distribution and mineralogical composition than other common sediment types and also plays an important role in maintaining yields of arable crops (Catt, 2001).

Although the environment is very important, no use of fertilizers and agricultural chemicals causes significant yield loss in rice production (Ku et al., 1999). Thus, environmental-friendly agricultural practice has been drawing a global attention as a promising alternative for sustainable food production. Lately circulated environmental-friendly agricultural materials include microbial products, amino acids, pyroligneous acid,

\footnotetext{
1 College of Agriculture and Life Sciences, Kyungpook National University, 702-701 Daegu, Republic of Korea

2 College of Agriculture and Life Sciences, Sunchon National University, 540-742 Sunchon, Republic of Korea

3 Department of Plant Biotechnology and Bioinductry, Catholic University of Daegu, 712-702 Kyungsan, Republic of Korea

* Corresponding author (E-mail: hexa20@hanmail.net)
}

charcoal, mixture of charcoal with pyroligneous acid (MCPA), chitosan and brown rice vinegar etc (Choi, 1998). Loess soils are among the most fertile soils in the world, principally because the abundance of silt particles ensures good water supply, aeration, root penetration, and seedbed production (Catt, 2001).

Research reports indicate favorable effects of MCPA and charcoal in improving soil productivity and yield in crops such as sweet potato, sorghum, melon, sugarcane (Tsuzuki et al., 1993; Uddin et al., 1994; Shibayama et al., 1998). However, there have been no attempts for the application of these materials on paddy soil and loess "Hwangto" for rice, which is one of the most important crops in Asia.

Therefore, this study was carried out to investigate the effect of environmentally-friendly materials treated in paddy soils and loess soil "Hwangto" on the growth and yield of rice.

\section{MATERIALS AND METHODS}

Experiments were carried out in 2002 at the experimental field of Kyungpook National University, Daegu, Korea. A Korean rice variety, Ilpoombyo, which was obtained from the Provincial Agricultural Research and Extension Services, Kyungpook Province and MCPA obtained from the Korean Forest Research Institute were used in this study. Seeds were pre-germinated for 48 hours in tap water in the dark at $30^{\circ} \mathrm{C}$ and then $130 \mathrm{~g}$ of germinated seeds were sown in a seedling tray (58x $28 \times 3 \mathrm{~cm})$. Thirty days after sowing, three seedlings were transplanted per pot (1/2000a).

The experiment was laid out in a randomized complete block design with three replications. MCPA was 
applied at $300 \mathrm{~kg}\left(10 \mathrm{a}^{-1}\right) 10$ days before transplanting. The different environmentally friendly soil treatments were as follows: Paddy soil (P), loess "Hwangto" (H), Paddy soil (P) + pyroligneous acid (PA), Paddy soil + charcoal (C) and Paddy soil (P) + Mixture of Charcoal and Pyroligneous Acid (MCPA). Other management practices were employed as recommended by Agricultural Research \& Extension Services.

\section{Agronomic characteristics}

Plant height and number of tillers were recorded at the heading stage. Yield and yield components such as number of panicles, number of spikelets per panicle, 1000 grains weight and ripening ratio were determined at harvest. Seed samples were taken at maturity, then were milled and separated as percentage of head rice, immature, damaged and dead grains.

\section{Chlorophyll content and root Activity}

Chlorophyll content was measured using a portable device SPAD-501 (Minolta Co. Japan) and was expressed by SPAD value (Yoshida et al., 1972). The oxidizing activity of the roots was determined by measuring oxidation of a-naphthylamine (Ota, 1970) at 30 days after transplanting. Fresh roots $(1 \mathrm{~g}, 1 \sim 2 \mathrm{~cm}$ from the tip of the middle roots) were transferred into a $150 \mathrm{ml}$ flask containing $50 \mathrm{ml}$ of $20 \mathrm{ppm}$ a -naphthylamine. The flasks were incubated for 3 hours at room temperature in an end-over-end shaker. After incubation, the aliquots were filtered and $2 \mathrm{ml}$ of filtrate was mixed with $1 \mathrm{ml}$ of $100 \mathrm{ppm} \mathrm{NaNO}_{2}$ and $1 \mathrm{ml}$ sulphanilic acid. Absorbance was measured at $510 \mathrm{~nm}$ after $30 \sim 60$ minutes of incubation.

\section{Soil analysis and chemical properties}

The soil was sampled at $0 \sim 15 \mathrm{~cm}$ depth from the surface layer at the heading stage. The soil samples were dried in air and then sieved through $2 \mathrm{~mm}$ mesh, and their chemical properties were analyzed. Soil pH (1:5 soil water ratio) was determined by using a $\mathrm{pH}$ meter (Orion, model 420A), organic matter (O.M.) contents and available phosphorus $\left(\mathrm{P}_{2} \mathrm{O}_{5}\right)$ content were determined according to the method of USSLS (1954). After extraction in $\mathrm{IN}-\mathrm{NH}_{4} \mathrm{OAc}$ solution, exchangeable $\mathrm{K}$, $\mathrm{Ca}$ and $\mathrm{Mg}$ were measured using an atom absorption spectrophotometer.

\section{RESULTS AND DISCUSSIONS}

Chemical properties of soils treated with various environmentally-friendly materials are summarized in Table 1. Loess soil type "Hwangto" compared to the other treatments showed low $\mathrm{pH}, \mathrm{P}_{2} \mathrm{O}_{5}$, EC and organic matter, whilst paddy soils $(\mathrm{P})$ treated with pyroligneous acid (PA), charcoal (C) and the mixture of charcoal and pyroligneous acid (MCPA) contained high organic matter but exchangeable cations ( $\mathrm{Ca}, \mathrm{Mg}, \mathrm{K}$ ), $\mathrm{pH}$ and $\mathrm{Na}$ showed similar trends among the treatments with the exception of loess "Hwangto" soil which showed low Ca, $\mathrm{Na}$ and high $\mathrm{Mg}$. Available phosphorus contents were as follows: $46.5 \mathrm{mg} \cdot \mathrm{kg}^{-1} \mathrm{P}+\mathrm{C}, \quad 43.6 \mathrm{mg} \cdot \mathrm{kg}^{-1} \mathrm{P}+\mathrm{MCPA}$, $32.7 \mathrm{mg} \cdot \mathrm{kg}^{-1} \mathrm{P}, 32.1 \mathrm{mg} \cdot \mathrm{kg}^{-1} \mathrm{P}+\mathrm{PA}$ and $2.1 \mathrm{mg} \cdot \mathrm{kg}^{-1}$ in loess soil "Hwangto", respectively.

EC contents decreased in soils treated with environmentally-friendly materials. Organic matter in paddy soil treated with MCPA was high with $2.13 \%$ and this had an important effect on some parameters of the soil chemical properties.

The results of the present study showed that the addition of these materials exerted beneficial effects in increasing the nutrient elements uptake and whereby improving the soil physicochemical properties, especially by $\mathrm{P}+\mathrm{PA}, \mathrm{P}+\mathrm{C}$ and $\mathrm{P}+\mathrm{MCPA}$ treatments. Ichikawa and Ota (1982) reported that PA improved the soil properties. Doran (1982) also reported that PA played a role as soil disinfectant.

The effects of different soil treatments on root activity at 30 days after seeding are shown in Figure 1. Root

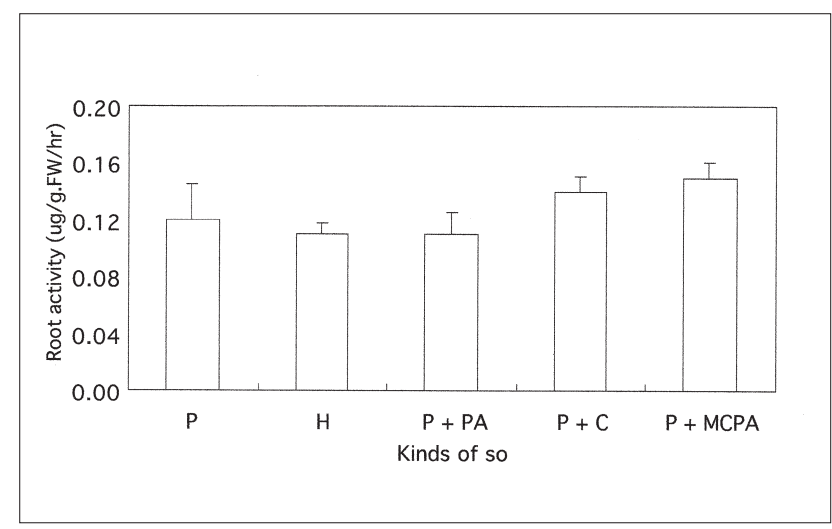

Fig. 1. Effects of different kinds of soil on root activity at 30days after seedling.

P: paddy, H: hwangto PA: pyroligneous acid, C: charcoal, MCPA: the mixture of charcoal with pyroligneous acid.

Table 1. Physico-chemical properties of soils treated with different environmentally friendly materials

\begin{tabular}{ccccccccc}
\hline Kinds of soil & $\begin{array}{c}\mathrm{pH} \\
(1: 5)\end{array}$ & $\begin{array}{c}\mathrm{EC} \\
(1: 5)\end{array}$ & $\begin{array}{c}\mathrm{OM} \\
(\%)\end{array}$ & $\begin{array}{c}\mathrm{AV} \cdot \mathrm{P}_{2} \mathrm{O}_{5} \\
\left(\mathrm{mg} \mathrm{kg}^{-1}\right)\end{array}$ & $\mathrm{K}$ & $\mathrm{Ca}$ & $\mathrm{Mg}$ & $\mathrm{Na}$ \\
\hline P & 6.96 & 0.84 & 1.73 & 32.7 & 0.31 & 6.11 & 1.88 & 0.66 \\
H & 6.04 & 0.16 & 1.25 & 2.1 & 0.20 & 4.99 & 3.42 & 0.17 \\
P + PA & 6.95 & 0.33 & 1.48 & 32.1 & 0.19 & 6.51 & 1.95 & 0.27 \\
P + C & 7.31 & 0.28 & 1.65 & 46.5 & 0.18 & 6.66 & 2.03 & 0.26 \\
P + MCPA & 7.19 & 0.27 & 2.13 & 43.6 & 0.21 & 6.69 & 1.91 \\
\hline
\end{tabular}

P: paddy, H: hwangto PA: pyroligneous acid, C: charcoal, MCPA: the mixture of charcoal with pyroligneous acid. 
activity was higher at the maximum tillering stage with the exception of loess soil "Hwangto" which showed the lower root activity at the stage. Root activity in $\mathrm{P}+\mathrm{C}$ was highest as 55.1 ( $\mu \mathrm{g} / \mathrm{g} . \mathrm{FW} / \mathrm{hr})$, and that in paddy soil and paddy soil + MCPA was 50.5 ( $\mu \mathrm{g} / \mathrm{g} . \mathrm{FW} / \mathrm{hr})$ and 46.9 ( $\mu \mathrm{g} / \mathrm{g} . \mathrm{FW} / \mathrm{hr})$, respectively. This result suggests that application of these materials affected the root activity of rice plant thus, possibly contributed to improve nutrient uptake.

Root activity was improved immensely with the application of the environmentally friendly materials in our study. This finding is in agreement with Tsuzuki et al. (1989) who reported that branch root formation was accelerated in MCPA treated rice crop. Shirakawa et al. (1993) reported that with the application of MCPA helped improve the physiological activities in the rice crop. The addition of PA, charcoal and MCPA on paddy soil influenced the production of sufficient roots to provide water and nutrients for the extended roots at 30 days (Fig. 2).

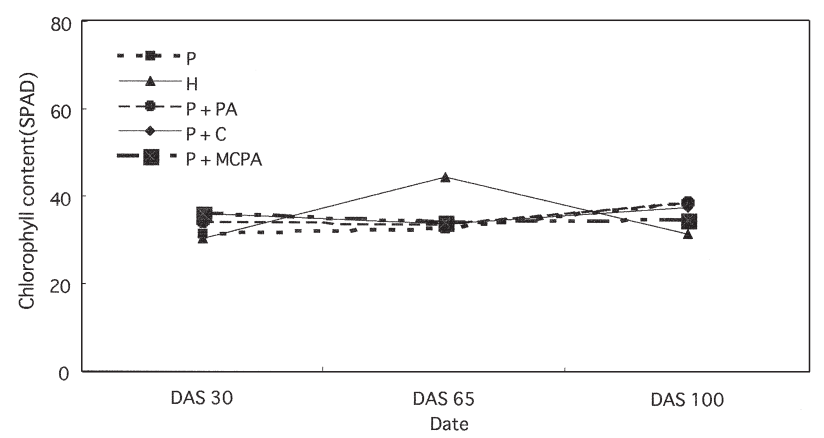

Fig. 2. Changes in the chlorophyll content in leaves of rice plants grown in paddy soil treated with different kinds of environmentally friendly materials.

DAS: days after seeding.

Leaf chlorophyll content responded similarly in all treatments except in loess soil "Hwangto" treatment, where chlorophyll content was significantly low at the early seedling stage but was increased above the levels observed in other treatments at the maximum seedling stage (Fig. 2). Similar response was also observed in plant height (data not shown). As chlorophyll is an important factor in photosynthesis, photosynthesis activity might have a similar response as chlorophyll content in loess soil "Hwangto" treatment.

Table 2 shows the effect of environmentally friendly materials on the appearance quality of brown rice. Head rice percent was significantly affected by the treatments, and it was 90.2 , 86.2, and $77.7 \%$ in paddy soils mixed with PA, charcoal and P + MCPA, respectively. Occurrence of immature grains and damaged grains were also affected by the soil treatments. Occurrence of immature grains were significantly increased by Hwangto and P + MCPA treatments but not by other treatments. Damaged grains were significantly decreased only by P + PA treatment. However, occurrence of dead grains were not affected by any treatment.
Table 2. Effect of different kinds of environmentally friendly soil treatments on appearance quality of brown rice

\begin{tabular}{ccccc}
\hline $\begin{array}{c}\text { Kinds of } \\
\text { soil }\end{array}$ & $\begin{array}{c}\text { Head rice } \\
(\%)\end{array}$ & $\begin{array}{c}\text { Immature } \\
\text { grains } \\
(\%)\end{array}$ & $\begin{array}{c}\text { Damaged } \\
\text { grains } \\
(\%)\end{array}$ & $\begin{array}{c}\text { Dead } \\
\text { grains } \\
(\%)\end{array}$ \\
\hline P & $85.0 \mathrm{~b}$ & $0.4 \mathrm{c}$ & $14.0 \mathrm{a}$ & $0.6 \mathrm{a}$ \\
H & $84.7 \mathrm{~b}$ & $3.5 \mathrm{~b}$ & $\begin{array}{c}11.6 \mathrm{ab} \\
9.1 \mathrm{~b}\end{array}$ & $0.1 \mathrm{a}$ \\
$\mathrm{P}+\mathrm{PA}$ & $90.2 \mathrm{a}$ & $0.5 \mathrm{c}$ & $13.3 \mathrm{ab}$ & $0.1 \mathrm{a}$ \\
P + C & $86.2 \mathrm{~b}$ & $0.4 \mathrm{c}$ & $12.8 \mathrm{ab}$ & $3.2 \mathrm{a}$ \\
$\mathrm{P}+\mathrm{MCPA}$ & $77.7 \mathrm{c}$ & $6.3 \mathrm{a}$ & &
\end{tabular}

P: paddy, H: hwangto PA: pyroligneous acid, C: charcoal, MCPA: the mixture of charcoal with pyroligneous acid. Means within a row with the same letter do not differ significantly at $\mathrm{p}<0.05$ with LSD.

Effects of different kinds of environmentally friendly soil treatments on yield components in rice are shown in Table 3. There were significant differences in the number of spikelets in P + PA showed the highest with 89.3, whereas P + MCPA was seen with 38.0 been the lowest number of spikelets and ripening ratio with $65.0 \%$, the argument to this low values in these yield components might be at the time of harvest emphasis were based on paddy soil plot, but not for the rest plots.

Significant differences were seen in 1,000 weight grains where paddy soil recorded $18.6 \mathrm{~g}$ with loess soil "Hwangto" showing $20.2 \mathrm{~g}$, whilst in the number of panicles P + MCPA was (24.6) indicated the highest, with the lowest (12) in paddy soil. Thus, it clearly shows the role in which these environmentally friendly materials help during the crop establishment in order to achieve good yield.

Table 3. Effect of different kinds of environmentally friendly soil treatments on yield components in rice

\begin{tabular}{ccccc}
\hline $\begin{array}{c}\text { Kinds of } \\
\text { soil }\end{array}$ & $\begin{array}{c}\text { No. of } \\
\text { Spikelet } \\
\left(\text { no. panicle }{ }^{-1}\right)\end{array}$ & $\begin{array}{c}\text { Ripening } \\
\text { ratio } \\
(\%)\end{array}$ & $\begin{array}{c}\text { Wt. of } \\
1,000 \text { grains } \\
(\mathrm{g})\end{array}$ & $\begin{array}{c}\text { No. of } \\
\text { panicle } \\
\left(\text { no. pot }^{-1}\right)\end{array}$ \\
\hline P & $77.9 \mathrm{ab}$ & $79.6 \mathrm{a}$ & $18.6 \mathrm{~d}$ & $12 \mathrm{e}$ \\
H & $68.0 \mathrm{bc}$ & $78.4 \mathrm{a}$ & $20.2 \mathrm{a}$ & $15 \mathrm{c}$ \\
$\mathrm{P}+\mathrm{PA}$ & $89.3 \mathrm{a}$ & $86.0 \mathrm{a}$ & $19.5 \mathrm{c}$ & $12.6 \mathrm{~d}$ \\
$\mathrm{P}+\mathrm{C}$ & $58.6 \mathrm{c}$ & $79.6 \mathrm{a}$ & $19.5 \mathrm{c}$ & $16.4 \mathrm{~b}$ \\
$\mathrm{P}+\mathrm{MCPA}$ & $38.0 \mathrm{~d}$ & $65.0 \mathrm{~b}$ & $19.8 \mathrm{~b}$ & $24.6 \mathrm{a}$ \\
\hline
\end{tabular}

P: paddy, H: hwangto PA: pyroligneous acid, C: charcoal, MCPA: the mixture of charcoal with pyroligneous acid. Means within a row with the same letter do not differ significantly at $\mathrm{p}<0.05$ with LSD.

Effects of different kinds of environmentally friendly soil treatments on rice yield are shown in Fig. 3. Yield was increased significantly by $\mathrm{P}+\mathrm{PA}$, decreased by $\mathrm{P}+$ MCPA, and unaffected by other treatments. Similar yield increase by PA was also reported by Ichikawa et al. (1982) and the increase was attributed to the improved soil properties by PA application.

Yield components were also affected by the treatment of environmentally friendly materials. Number of 


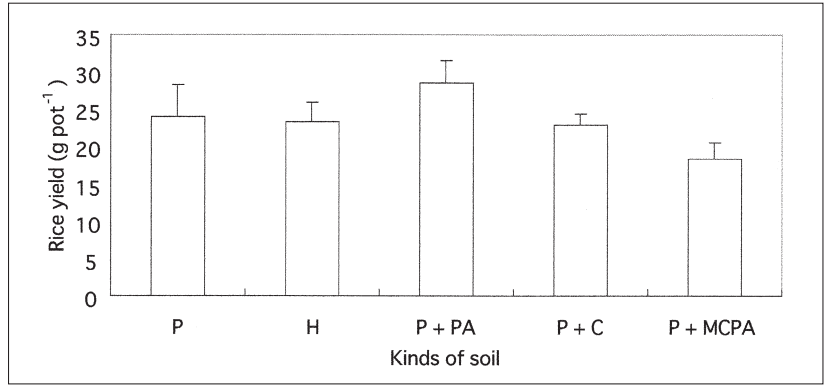

Fig. 3. Effects of different kinds of environmentally friendly soil treatments on rice yield.

P: paddy, H: hwangto PA: pyroligneous acid, C: charcoal, MCPA: the mixture of charcoal with pyroligneous acid.

spikelets were significantly decreased by $\mathrm{P}+\mathrm{C}$ and $\mathrm{P}+$ MCPA. Ripening ratio was decreased only by $\mathrm{P}+\mathrm{MCPA}$. One thousand grain weight and number of panicles were significantly increased by all the treatment (Table 3). These results suggest that yield increase by $\mathrm{P}+\mathrm{C}$ is associated with increases in 1000 grain weight and number of panicles. On the contrary, yield decrease by $\mathrm{P}+$ MCPA is associated with decreased number of spikelets and ripening ratio.

Results in yield clearly showed an improvement in yield with the application of environmentally materials, however from our results obtained when the yield was investigated much of the emphasis was particular based on paddy soil plot at the time of harvesting, that is why there was a decreased in the number of spikelets and ripening ratios observed in $\mathrm{P}+\mathrm{MCPA}$, but in the case of the panicle number showed some significant increase. Tsuzuki et al. (1989) reported an increase in ear number and grain yield.

Environmentally friendly materials improve soil conditions and reduces damages from weeds and insects (and therefore reduces costs for insecticides and chemical fertilizers), thereby contributing to better growth and high grain yield.

These results demonstrate that similar or higher yields could be achieved with use of environmental friendly materials as with chemical fertilizers. Replacement of environmental friendly materials for chemical fertilizers and herbicides can help avoid the environmental problems such as water-quality deterioration, underground water and agricultural water pollution that is caused by leaching, soil degradation, ground pollution etc. A sustainable farming must produce adequate high-quality yields, be profitable, protect the environment and conserve the natural resources.

More research effort should be focused on the effective utilization of these environmentally friendly materials in the near future in order to reduce use of agro-chemicals which tend to be very expensive for farmers to purchase and at the same time to deteriorate our environment.

The utilization of these materials will improve agriculture productivity and would not only be a solution to the problem but might also maintain a sound environ- ment for years to come.

\section{ACKNOWLEDGEMENTS}

This work was supported by Kyungpook National University Research Team.

\section{REFERENCES}

Bouwnan A. F., 1990. Exchange of green house gases between terrestial ecosystems and the atmosphere: In "Soils and the greenhouse effect", A. F. Bouwnan, (ed), John Wiely \& Sons. Chichester. England. p. 61-127

Catt J. A., 2001. The agricultural importance of loess. Earth-Science Reviews 54: 213-229.

Choi K. S., 1998. Synthesis and properties of carboxyalkyl chistosan derivatives. J. Ind Eng. Chem. 4 (1) 19-25

Doran W. L., 1982. Acetic acid and pyroligneous acid in comparison with formaldehyde as soil disinfectants. J. Agr. Res. 44: $571-578$

Duxbury J. M. and Moiser A. R., 1993. Status and issue concerning agricultural emissions of greenhouse gases: In "Agricultural dimension of global climate change", H. M. Kaiser and T. Drennem, eds. St, Lucie Press. Delray Beach. Florida. p. 229-258

Ichikawa T. and Ota Y., 1982. Plant growth-regulating activity of pyroligneous acid: Effect of pyroligneous acid on the growth of rice seedlings. Jpn. J. Crop Sci. 51 (1): 14-17

Jones R. D. and Schwab A. P., 1993. Nitrate leaching and nitrate occurrence in a fine-textured soil. Soil Sci. 155: 272-282

Ku Y. C. and Seong K. Y., Song D. Y., Lee S. B., Huh I .B. and Koo H. M., 1999. Yield of rice cultivated with the use of fertilizer and pesticides. Korean J. of Weed Sci. 19 (1): 21-26

Ota. Y., 1970. Diagnostic methods for the measurement of root activity in rice plant. Jpn. Agric. Res. 5: 1-6

Shibayama H., Mashima K., Mitsutomi M. and Arima S., 1998. Effect of application of pyroligneous acid solution produced in Karatsu city on growth and free sugar contents of storage roots of sweet potatoes. Marine-and-Highland Bioscience Center Report 7: 15-23

Shirakawa N., Fukazawa M. and TER. ADA S., 1993. Studies on the pyroligneous acid IV. Plant physiological activities of several main components in pyrolignoues acid. Jpn. J. Crop Sci. 62: 168-189

Tsuzuki E., Wakiyama Y., Eto H. and Handa H., 1989. Effect of pyroligneous acid and mixture of charcoal with pyroligneous acid on the growth and yield of rice plant. Jpn. J. Crop Sci. 58 (4): $592-597$

Tsuzuki E., Ando S., Terao H., and Uchida Y., 1993. Effect of mixture of charcoal with pyroligneous acid on quality of melon (Cumis melo L.). Jpn. J. Crop Sci. 62: 170-171

Uddin S. M., Murayama S., Ishimine Y. and Tsuzuki E., 1994. Studies on sugarcane (Saccharum officinarum) cultivation 1: Effects of the mixture of charcoal with pyroligneous acid on cane and sugar yield of spring and rate on crops of sugarcane (Saccharum officinarum L.). Jpn. J. of Trop. Agri. 38 (4): 281-285

USSLS. 1954. pH reading of saturated soil paste. U.S Salinity Laboratory Staff (USSLS). p. 102. In "Diagnosis and improvement of saline and alkaline soils", L.A. Richards (ed.) USDA Agricultural Handbook 60. U.S Government Printing Office, Washington, D.C

Yoo S. H., 1999. Perspectives of sustainable agriculture in Korea. Proceedings of international symposium on farm mechanization for environment friendly agriculture. p. 139-163

Yoshida S., Douglas A. F., James H. C. and Kwanchai A. G., 1972. Laboratory manual for physiology studies of rice. IRRI, Philippines, p. 36-41 